\title{
PERBEDAAN ASUPAN ENERGI, LEMAK, SERAT DAN AKTIVITAS FISIK PADA ANAK OBESITAS DAN NON-OBESITAS USIA 3 - 5 TAHUN
}

\author{
Pramita Ariawati Putri, Etika Ratna Noer ${ }^{*}$ \\ Program Studi Ilmu Gizi Fakultas Kedokteran Universitas Diponegoro \\ Jl.Dr.Sutomo No.18, Semarang, Telp (024) 8453708, Email : gizifk@ undip.ac.id
}

\begin{abstract}
Background: Obesity is a nutritional problem that may have risk for health and must be prevented early. Obesity in preschool children (3 - 5years) was associated with adiposity rebound. The earlier adiposity rebound occurred, children more likely to be obese in adult. Factors that affecting occurrence of obesity is intakes of energy, fat, fiber and physical activity. The study aimed to determine differences intake of energy, fat, fiber and physical activity in children aged 3 - 5 years

Method : Design of the study was case control with age and sex matching from the students of Al-Azhar 14 Islamic playgroup and kindergarten in Semarang City. Subject were 30 children in case group (overweight and obesity) and 30 children in control group (normal children). Obesity determined by z-score BMI/age indicator. Normal criteria (z-score -2 $\geq 1 S D)$ overweight $(1 \geq 2 S D)$ and obese (>2SD). Energy, fat and fiber intake were calculated by semiquantitative food frequency questionaire (FFQ). Physical activity measured by physical activity recall. Data were analyzed by Independent t-test and Mann-Whitney test.
\end{abstract}

Results: Energy and fat intake in case group were higher than control group. There were a different intake of energy $(p=0,000)$ and fat $(p=0,000)$ between case and control group. There was no different intake of fiber $(p=0,311)$ and physical activity $(p=0,112)$ between case and control group.

Conclusion : there were different intake of energy and fat between obese and non-obese child.

Keywords : energy; fat; fiber; physical activity; children aged 3 - 5 years

\begin{abstract}
ABSTRAK
Latar Belakang : Obesitas adalah masalah gizi yang dapat membahayakan kesehatan dan harus ditangani sejak dini. Obesitas pada anak usia 3 - 5 tahun dikaitkan dengan semakin cepat terjadinya adiposity rebound, yang memungkinkan anak menjadi obesitas saat dewasa. Obesitas dapat dipengaruhi oleh asupan energi, lemak, serat dan aktivitas fisik. Penelitian ini bertujuan untuk mengetahui perbedaan asupan energi, lemak, serat dan aktivitas fisik pada anak usia 3 - 5 tahun.

Metode : Desain penelitian case control study dengan matching usia dan jenis kelamin pada KB-TK Islam AlAzhar 14 Semarang. Subjek terdiri dari 30 kelompok kasus (overweight dan obesitas) dan 30 kelompok kontrol (normal). Kriteria normal, overweight dan obesitas menggunakan indikator z-score IMT/U. Normal jika z-score -2 $\geq 1 S D$, overweight $(1 \geq 2 S D)$, dan obesitas (> $2 S D)$. Asupan energi, lemak dan serat dihitung menggunakan food frequency questionnaire (FFQ) semi kuantitatif dan aktivitas fisik menggunakan kuesioner recall aktivitas fisik. Analisis data menggunakan uji independent T test dan Mann-Whitney.

Hasil : Asupan energi dan lemak pada kelompok kasus lebih tinggi daripada kelompok kontrol. Terdapat perbedaan asupan energi $(p=0,000)$ dan lemak $(p=0,000)$ pada kedua kelompok. Tidak terdapat perbedaan asupan serat $(p=0,311)$ dan aktivitas fisik $(p=1,112)$ pada kedua kelompok.
\end{abstract}

Kesimpulan : Terdapat perbedaan asupan energi dan lemak pada anak obesitas dan tidak obesitas.

Kata Kunci: energi; lemak; serat; aktivitas fisik; obesitas; anak usia 3 - 5 tahun

\section{PENDAHULUAN}

Obesitas pada anak usia prasekolah adalah salah satu masalah gizi yang ada di Indonesia. Prevalensi gizi lebih pada anak usia prasekolah di Indonesia tahun 2007 - 2010 meningkat dari 12,2 menjadi $14 \%$. Sebanyak $13,8 \%$ anak laki - laki dan $14,2 \%$ anak perempuan di Indonesia mengalami obesitas. Prevalensi obesitas pada anak di Kota Semarang sendiri meningkat dari 3,56\% (2007) menjadi 3,8\% (2011). ${ }^{1,2,3}$ Masalah gizi lebih dapat membahayakan kesehatan anak karena mengakibatkan adanya penyakit degenerative seperti diabetes, tekanan darah tinggi, penyakit jantung, stroke, gout $^{4}$

Obesitas pada anak usia prasekolah (3 - 5 tahun) dikaitkan dengan adanya adiposity rebound yaitu peningkatan lemak secara cepat pada umur 5 - 6 tahun. ${ }^{5}$ Penelitian menunjukkan bahwa semakin cepat terjadi adiposity rebound maka semakin besar risiko anak menjadi obesitas saat dewasa. ${ }^{6}$ Obesitas dapat terjadi karena asupan yang berlebih tanpa diimbangi dengan aktivitas fisik. ${ }^{7}$ Penelitian di Amerika menunjukkan bahwa anak yang banyak mengonsumsi makanan padat energi, 
tinggi lemak dan rendah serat memiliki hubungan dengan tingginya massa lemak dan jaringan adiposa yang berlebih. ${ }^{8}$ Penelitian di Amerika dan Finlandia menunjukkan bahwa kelompok dengan asupan tinggi lemak mempunyai risiko 1,7 kali lebih besar dalam peningkatan berat badan kelompok dengan asupan rendah lemak, sedangkan asupan serat yang diperlukan anak karena dapat berfungsi untuk menurunkan risiko overweight dan obesitas masih kurang. ${ }^{9,10}$

Aktivitas fisik juga memegang peranan penting terhadap terjadinya obesitas pada anak. Adanya kemajuan teknologi membuat anak semakin pasif dan memiliki gaya hidup yang santai (sedentary lifestyle), anak lebih memilih menghabiskan waktu di depan televisi atau bermain games yang ada di computer. ${ }^{11}$ Penelitian menunjukkan anak yang melakukan sedentary lifestyle selama lebih dari 1 jam perhari memiliki resiko menjadi overweight. ${ }^{\mathbf{1 2}}$ Penelitian yang dilakukan pada anak SD di Semarang juga menunjukkan bahwa anak yang menggunakan kendaraan pribadi ke sekolah memiliki faktor risiko $3 \mathrm{x}$ lebih besar untuk menjadi obesitas. ${ }^{13}$ Jika anak sudah mengalami obesitas, maka akan menyulitkan anak untuk melakukan aktivitas fisik karena badan anak yang berukuran besar. ${ }^{14}$

Berdasarkan paparan di atas, peneliti ingin mengetahui apakah terdapat perbedaan asupan energi, lemak, serat dan aktivitas fisik antara anak yang obesitas dan tidak obesitas. Penelitian ini diharapkan dapat memberikan informasi pada masyarakat mengenai perbedaan asupan tinggi energi, lemak, serat dan aktivitas fisik dan dapat dijadikan sumber acuan dalam mengembangkan ilmu pengetahuan.

\section{METODE}

Jenis penelitian ini menggunakan desain case control study dengan matching usia dan jenis kelamin. Subjek penelitian adalah anak TK usia 35 tahun. Pengambilan subjek penelitian dengan metode random sampling. Penelitian ini dilaksanakan di KB - TK Islam Al - Azhar 14 Semarang karena sekolah ini merupakan sekolah swasta yang sebagian besar siswanya berasal dari golongan ekonomi menengah ke atas dan terdapat $25 \%$ anak dengan gizi lebih ${ }^{15}$. Pelaksanaan penelitian pada bulan Juli - September 2013. Jumlah subjek penelitian sebanyak 60 anak terdiri dari masing - masing 30 anak untuk kelompok kasus dan kelompok kontrol.

Kriteria Inklusi penelitian ini yaitu anak TK usia 3 - 5 tahun, untuk Kelompok kasus Z-skor dari indeks IMT/U >1SD, sedangkan kelompok kontrol Z-skor dari indeks IMT/U -2SD $\geq 1 \mathrm{SD}$, orang tua bersedia anak menjadi subjek penelitian dengan mengisi informed consent, tidak memiliki kelainan genetik/ hormonal. Kriteria eksklusi penelitian ini yaitu mengundurkan diri menjadi subjek penelitian dan pindah sekolah.

Variabel dependent dalam penelitian ini adalah kejadian obesitas pada anak usia $3-5$ tahun dan variabel independent adalah asupan energi, lemak, serat dan aktivitas fisik. Obesitas dihitung dengan Z-skor IMT/U. Kategori overweight $\mathrm{IMT} / \mathrm{U} 1 \geq 2 \mathrm{SD}$, obesitas IMT/U > 2SD dan normal yaitu IMT/U $-2 \geq 1 \mathrm{SD}$. Pengolahan dan analisa data IMT/U menggunakan software $\mathrm{WHO}$ Anthroplus. ${ }^{16}$

Data karakteristik subjek yaitu pekerjaan ayah, pendidikan ibu dan pekerjaan ibu didapatkan melalui wawancara langsung. Data asupan energi, lemak dan serat diperoleh melalui kuesioner dengan wawancara FFQ (Food Frequency Questionaire) semi kuantitatif. Kategori asupan energi baik jika asupan $\leq 100 \%$ TEE dan lebih jika asupan $>100 \%$ TEE. Kategori asupan lemak baik jika asupan $\leq 30 \%$ TEE dan lebih jika asupan $>$ $30 \%$ TEE. ${ }^{17}$ Asupan serat dikategorikan cukup jika asupan serat dalam sehari $\geq(5+$ (umur dalam tahun)) gram/hari dan kurang jika asupan < (5+(umur dalam tahun)) gram/hari. ${ }^{18}$ Aktivitas fisik yaitu kegiatan yang dilakukan sehari - hari didapatkan menggunakan formulir recall aktivitas fisik 3x24 jam. Data kategori aktivitas dikelompokkan menurut Physical Activity Level $(P A L)$ yang di dapatkan dari jumlah energi yang dikeluarkan (Physical Activity Ratio / PAR) dari tiap kegiatan, dikalikan dengan alokasi waktu saat melakukan kegiatan dinyatakan dalam jam, kemudian dibagi 24 jam yang kemudian di rata rata selama 3 hari. Aktivitas fisik dikatakan sangat ringan jika $\mathrm{PAL}<1,45$ dan sedang jika $\geq 1,45{ }^{19,20}$ Pengolahan dan analisa data asupan energi, lemak dan serat menggunakan software Nutrisurvey.

Pengumpulan data diawali dengan skrining di KB - TK Islam Al-Azhar 14 Semarang. Pengambilan subjek penelitian dilakukan dengan random sampling dari semua anggota populasi sampai jumlah subjek terpenuhi. Data yang dikumpulkan yaitu identitas subjek, IMT, data asupan energi, lemak dan serat, serta aktivitas fisik. Analisa data untuk mengetahui perbedaan menggunakan uji Independent T-test untuk data normaldan untuk data tidak normal menggunakan uji Mann-Whitney. 
HASIL PENELITIAN

Karakteristik Subjek Penelitian

Subjek penelitian berjumlah 60 anak yang terdiri dari 32 anak perempuan dan 28 anak laki laki. Usia dominan ada pada usia 4 - 5 tahun. Sebagian besar pekerjaan ayah pada kelompok kasus dan kontrol adalah pegawai swasta, Pendidikan ibu pada kelompok kasus dan kontrol memiliki proporsi sama, sebagian besar ibu adalah sarjana. Sebagian besar ibu pada kelompok kasus dan kontrol bekerja di kantor.

Tabel 1. Karakteristik subjek penelitian

\begin{tabular}{lcccc}
\hline \multicolumn{1}{c}{ Variabel } & \multicolumn{2}{c}{ Kasus } & \multicolumn{3}{c}{ Kontrol } \\
\cline { 2 - 5 } & $\mathbf{n}$ & $\mathbf{\%}$ & $\mathbf{n}$ & \% \\
\hline Pekerjaan Ayah & & & & \\
PNS/TNI/POLRI & 7 & 23,33 & 7 & $23,33 \%$ \\
Pegawai Swasta & 12 & 40 & 14 & $46,67 \%$ \\
Wiraswasta & 11 & 36,67 & 9 & $30 \%$ \\
Pendidikan Ibu & & & & \\
Sarjana & 27 & 90,00 & 27 & 90,00 \\
Diploma & 3 & 10,00 & 3 & 10,00 \\
Pekerjaan Ibu & & & & \\
Ibu Rumah & & & & \\
Tangga & 4 & 13,33 & 6 & 80,00 \\
Bekerja & 26 & 86,67 & 24 & \\
\hline
\end{tabular}

Distribusi z-skor menurut IMT/U menunjukkan kelompok kasus memiliki rerata 2,41 SD dan menunjukkan bahwa rerata pada kelompok kasus kelompok kontrol memiliki rerata $-0,34 \mathrm{SD}$. Distribusi rerata z-skor menurut TB/U lebih tinggi yaitu $-0,73$ SD dibandingkan dengan kelompok kontrol yang memiliki rerata -1,31 SD.

Tabel 2. Distribusi Z-skor

\begin{tabular}{lcccccc}
\hline \multicolumn{1}{c}{ Variabel } & \multicolumn{3}{c}{ Kasus } & \multicolumn{3}{c}{ Kontrol } \\
\cline { 2 - 7 } & \multicolumn{3}{c}{$\mathbf{n = 3 0}$} & \multicolumn{3}{c}{$\mathbf{n = 3 0}$} \\
\hline & Rerata \pm SD & Min & Maks & Rerata \pm SD & Min & Maks \\
\hline $\begin{array}{l}\text { Z-skor IMT/U } \\
\text { (SD) }\end{array}$ & $2,41 \pm 1,13$ & 1,06 & 5,20 & $-0,34 \pm 0,72$ & $-1,75$ & 0,61 \\
\hline $\begin{array}{l}\text { Z-skor TB/U } \\
\text { (SD) }\end{array}$ & $-0,73 \pm 1,17$ & $-3,04$ & 1,77 & $-1,31 \pm 0,86$ & $-2,44$ & 0,69 \\
\hline
\end{tabular}

Asupan energi pada kelompok kasus memiliki rerata $1687 \mathrm{kkal} / \mathrm{hari}$, jumlah ini lebih besar dibandingkan kelompok kontrol yang memiliki rerata asupan energi $1309 \mathrm{kkal} / \mathrm{hari}$. Hal yang sama juga terjadi pada asupan lemak kelompok kasus yang lebih tinggi daripada kelompok kontrol, rerata asupan lemak masing - masing kelompok adalah 67,3 gram/hari dan 49,2 gram/hari.

Tabel 3. Deskripsi asupan energi dan lemak berdasarkan kelompok kasus dan control

\begin{tabular}{lcccccc}
\hline \multicolumn{1}{c}{ Variabel } & \multicolumn{3}{c}{ Kasus } & \multicolumn{3}{c}{ Kontrol } \\
\cline { 2 - 7 } & Rerata \pm SD & Min & Maks & Rerata \pm SD & Min & Maks \\
\hline Asupan energi (kkal) & $1687 \pm 221,5$ & 1213,4 & 2371,8 & $1,309 \pm 193,5$ & 986,5 & 1831,3 \\
Asupan lemak (g) & $67,3 \pm 9,4$ & 37,4 & 94,7 & $49,2 \pm 11,8$ & 31,9 & 68,4 \\
\hline
\end{tabular}


Asupan serat pada kedua kelompok tergolong masih rendah. Asupan serat pada kelompok kasus sebesar 6,2 gram/hari dan pada kelompok kontrol sebesar 7,5 gram/hari. Tingkat aktivitas fisik pada kedua kelompok juga termasuk dalam kategori sangat ringan. Ini ditunjukkan dari nilai median tingkat aktivitas kelompok kasus yaitu 1,29 dan 1,32 pada kelompok kontrol.

Tabel 4. Deskripsi asupan serat dan aktivitas fisik berdasarkan kelompok kasus dan control

\begin{tabular}{lcccccc}
\hline \multicolumn{1}{c}{ Variabel } & \multicolumn{3}{c}{ Kasus } & \multicolumn{3}{c}{ Kontrol } \\
\cline { 2 - 7 } & Median & Min & Maks & Median & Min & Maks \\
\hline Asupan serat (g) & 6,2 & 4,1 & 14,5 & 7,5 & 2,5 & 14,7 \\
Aktivitas fisik & 1,29 & 1,21 & 1,47 & 1,32 & 1,21 & 1,7 \\
(kkal/24j) & & & & & & \\
\hline
\end{tabular}

Perbedaan Asupan Energi, Lemak, Serat dan Aktivitas Fisik pada Anak Usia 3 - 5 Tahun.
Data perbedaan asupan energi, lemak, serat dan aktivitas fisik disajikan pada Tabel 5 .

Tabel 5. Asupan Energi, Lemak, Serat dan Aktivitas Fisik pada anak usia 3 - 5 tahun

\begin{tabular}{|c|c|c|c|c|c|}
\hline \multirow[t]{2}{*}{ Faktor Risiko } & \multicolumn{2}{|c|}{ Kasus } & \multicolumn{2}{|c|}{ Kontrol } & \multirow[t]{2}{*}{$\mathbf{p}$} \\
\hline & $\mathbf{n}$ & $\%$ & $\mathbf{N}$ & $\%$ & \\
\hline \multicolumn{6}{|l|}{ Asupan energi (kkal) } \\
\hline Baik $(\leq 100 \%$ TEE $)$ & 18 & 60,00 & 23 & 76,67 & 0,000 \\
\hline Lebih (> 100\% TEE) & 12 & 40,00 & 7 & 23,33 & \\
\hline \multicolumn{6}{|l|}{ Asupan Lemak } \\
\hline Baik ( $\leq 30 \%$ TEE) & 6 & 20,00 & 17 & 56,67 & 0,000 \\
\hline Lebih (> 30\% TEE) & 24 & 80,00 & 13 & 43,33 & \\
\hline \multicolumn{6}{|l|}{ Asupan Serat } \\
\hline Baik ( $\geq(5+$ umur $)$ gram $)$ & 6 & 20,00 & 2 & 6,67 & 0,311 \\
\hline Kurang $(<(5+$ umur $)$ gram $)$ & 24 & 80,00 & 28 & 93,33 & \\
\hline \multicolumn{6}{|l|}{ Aktivitas Fisik } \\
\hline Sangat ringan $(<1,45)$ & 28 & 93,33 & 28 & 93,33 & 0,112 \\
\hline Sedang $(\geq 1,45)$ & 2 & 6,67 & 2 & 6,67 & \\
\hline
\end{tabular}

Berdasarkan pada tabel 5, data asupan energi dan lemak dianalisis menggunakan uji independent $T$-test, sedangkan untuk asupan serat dan aktivitas fisik menggunakan uji Mann-whitney. Terdapat perbedaan asupan lemak $(\mathrm{p}=0,000)$ dan energi $(\mathrm{p}=0,000)$ antara kelompok kasus dan kontrol. Tidak terdapat perbedaan asupan serat $(\mathrm{p}=0,311)$ dan aktivitas fisik $(\mathrm{p}=0,112)$. Asupan energi dan lemak pada kelompok kasus lebih tinggi karena konsumsi sumber karbohidrat dan lauk hewani yang lebih besar dilihat dari jumlah dan frekuensinya.

\section{PEMBAHASAN}

Obesitas didefinisikan sebagai kelainan atau penyakit yang ditandai dengan adanya penimbunan jaringan lemak tubuh secara berlebihan karena adanya surplus energi dimana asupan makanan lebih besar daripada energi yang digunakan. Energi yang dikonsumsi seharusnya sesuai dengan kebutuhan tubuh manusia. Energi dalam tubuh digunakan untuk metabolisme basal, aktivitas fisik, specific dynamic action (SDA) dan pada anak energi juga digunakan untuk faktor pertumbuhan. Obesitas pada anak usia 3 - 5 tahun dapat meningkatkan risiko terjadinya obesitas anak pada saat dewasa. Ini terkait dengan adanya peningkatan massa lemak dengan cepat yang disebut adiposity rebound. Penelitian menunjukkan, semakin cepat terjadi adiposity rebound pada anak, maka semakin besar risiko anak menjadi overweight atau obesitas di kemudian harinya. ${ }^{21}$ Penelitian lain menunjukkan bahwa pada bayi dan anak yang obesitas, sekitar $26,5 \%$ akan tetap obesitas untuk 2 dekade berikutnya dan $80 \%$ remaja yang obesitas akan menjadi dewasa yang obesitas. ${ }^{4,7}$ Terjadinya obesitas akan membahayakan kesehatan anak karena mengakibatkan adanya penyakit degenerative seperti diabetes, tekanan darah tinggi, penyakit jantung, stroke, gout. ${ }^{4}$ 
Asupan makanan merupakan faktor utama yang membuat terjadinya obesitas. Penelitian di Amerika menunjukkan bahwa anak yang banyak mengonsumsi makanan padat energi, tinggi lemak dan rendah serat memiliki hubungan dengan tingginya massa lemak dan jaringan adiposa yang berlebih. ${ }^{8}$. Kurangnya aktivitas fisik yang dilakukan oleh anak juga dapat menyebabkan terjadinya obesitas karena adanya surplus energi. Penelitian menunjukkan anak yang melakukan sedentary lifestyle selama lebih dari 1 jam perhari memiliki resiko menjadi overweight. ${ }^{12}$

Kejadian obesitas pada anak prasekolah dalam penelitian ini ditunjukkan dengan z-score menurut IMT/U anak pada kelompok kasus yang memiliki rerata $>2 \mathrm{SD}$. Rerata $z$-score menurut TB/U pada kedua kelompok menunjukkan angka yang termasuk dalam kategori normal $(\leq-2 \mathrm{SD})$ yaitu yaitu $-0,73$ pada kelompok kasus dan $-1,31$ pada kelompok kontrol. Terdapat 2 anak tergolong dalam kategori pendek dan 1 anak tergolong dalam kategori sangat pendek pada kelompok kasus sedangkan pada kelompok kontrol terdapat 10 anak tergolong dalam kategori pendek.

Hasil penelitian menunjukkan bahwa terdapat perbedaan asupan energi pada kelompok kasus dan kontrol $(\mathrm{p}=0,000)$, namun asupan energi pada kelompok kasus dan kontrol sebagian besar tergolong baik yaitu 18 anak $(60,00 \%)$ pada kelompok kasus dan 23 anak $(76,67 \%)$ pada kelompok kontrol. Asupan energi pada kelompok kasus lebih tinggi karena besarnya porsi anak dalam mengonsumsi karbohidrat. Asupan karbohidrat pada kelompok kasus berkontribusi $>50 \%$ dari asupan sehari. Anak pada kelompok kasus juga mengonsumsi lauk baik hewani $(\geq 40$ gram/hari) maupun nabati ( $\geq 40$ gram/hari) dalam porsi yang lebih besar.

Anak usia 3 - 5 tahun sudah menjadi konsumen aktif yaitu dapat memilih makanan sendiri. Sebagian besar orangtua anak yang bekerja membuat anak lebih banyak menghabiskan waktu bersama pembantu rumah tangga (PRT). PRT cenderung memberikan makanan yang diminta oleh anak, baik dalam pemilihan jenis makanan ataupun dalam porsi makan anak. Anak pada kelompok kasus juga masih mengonsumsi camilan tinggi energi namun rendah nutrisi lain seperti burger, kebab, chiki, es krim dan coklat.

Asupan energi yang berlebihan secara terus menerus dan tidak digunakan oleh tubuh akan mengakibatkan energi akan disimpan dalam bentuk jaringan lemak di dalam tubuh. Semakin banyak energi yang tidak digunakan maka akan meningkatkan jaringan lemak dalam tubuh. ${ }^{22}$ Asupan energi yang berlebihan juga dapat mengakibatkan resistensi leptin. Leptin berasal dari jaringan adiposa. Semakin banyak jaringan adiposa maka kadar leptin juga akan semakin tinggi. Adanya leptin seharusnya dapat menurunkan nafsu dan asupan makan, namun karena adanya resistensi leptin pada orang obesitas hal tersebut tidak dapat terjadi. $^{7}$

Penelitian ini menunjukkan bahwa terdapat perbedaan asupan lemak antara kelompok kasus dan kontrol $(\mathrm{p}=0,000)$. Asupan lemak lebih pada kelompok kasus lebih tinggi (24 anak, 80\%) dibanding dengan kelompok kontrol 13 anak $(43,33 \%)$ karena anak pada kelompok kasus lebih banyak dan sering mengonsumsi sumber hewani dibandingkan sumber nabati. Lauk dari sumber hewani mengandung lebih banyak lemak, selain itu makanan yang dikonsumsi juga banyak diolah dengan cara digoreng dengan menggunakan mentega atau minyak. Sumber lemak yang paling banyak dikonsumsi oleh subjek adalah lauk hewani (daging). Penelitian lain menunjukkan bahwa peningkatan asupan daging meningkatkan risiko obesitas sebesar 1,46 kali. ${ }^{23}$ Selain itu, sebagian besar orangtua anak pada kelompok kasus tidak membatasi asupan makanan termasuk konsumsi lauk hewani dan selalu memberikan makanan yang diminta oleh anak, minimal dalam seminggu sekali anak mengonsumsi makanan fastfood atau junkfood.

Asupan lemak yang melebihi kebutuhan dapat menyebabkan obesitas karena lemak memberikan kontribusi yang cukup tinggi yaitu 9 $\mathrm{kkal} / \mathrm{gram}$. Lemak cenderung dikonsumsi lebih banyak karena karakteristik rasa gurih yang disukai oleh anak. Hal ini sesuai dengan penelitian yang menyebutkan bahwa anak dengan obesitas mempunyai kebiasaan mengkonsumsi makanan cepat saji (junk food dan fastfood), yang umumnya memiliki energi tinggi karena $40-50 \%$ nya berasal dari lemak. Berbeda dengan karbohidrat dan protein, lemak memiliki kapasitas penyimpanan dalam tubuh yang tidak terbatas, selain itu kelebihan asupan lemak tidak diiringi dengan oksidasi lemak sehingga sekitar 96\% lemak akan disimpan dalam jaringan lemak. ${ }^{9,23,24}$

Penelitian ini menunjukkan bahwa tidak ada perbedaan asupan serat antara dua kelompok $(\mathrm{p}=0,311)$. Kedua kelompok memiliki asupan serat yang tergolong rendah. Asupan serat dalam kategori baik pada kelompok kontrol didapatkan sejumlah 6 anak (20\%) sedangkan pada kelompok kasus hanya 2 anak $(6,67 \%)$. Hasil ini berbeda 
dengan penelitian lain yang menyebutkan bahwa populasi yang banyak mengonsumsi karbohidrat kompleks dan tinggi asupan serat lebih banyak memiliki prevalensi obesitas yang lebih rendah. ${ }^{25}$ Rendahnya asupan serat pada kedua kelompok dapat disebabkan karena sulitnya memenuhi porsi serat sehari sesuai anjuran yang termasuk tinggi untuk anak. Asupan serat rendah pada anak disebabkan karena kurangnya anak mengonsumsi sumber serat. Sebagian besar serat yang dikonsumsi oleh anak hanya berasal dari makanan pokok.

Asupan serat juga masih rendah karena anak yang sudah dapat memilih makanannya sendiri tidak menyukai sayur - sayuran yang merupakan sumber utama serat. Anak yang sebagian besar menghabiskan waktu dengan diasuh oleh PRT juga tidak dimotivasi untuk mengonsumsi sayur. Hal ini sesuai dengan penelitian serupa di Semarang yang menunjukkan bahwa sekitar $90 \%$ anak mengonsumsi sayuran $<3$ porsi sehari. Faktor sosial budaya di Indonesia juga turut berperan, seperti tidak membiasakan mengonsumsi buah dan sayur dalam jumlah yang banyak, oleh karena itu sangat sulit didapatkan asupan serat yang memenuhi anjuran konsumsi perhari. Asupan serat yang cukup dapat membantu mengontrol berat badan. Serat memiliki energy density yang rendah sehingga dapat meningkatkan rasa kenyang. Saat pencernaan serat akan menarik air dan membentuk gel yang memperlambat jalannya pencernaan sehingga membuat rasa kenyang yang lebih lama. ${ }^{23}$ Beberapa jenis serat seperti pectin, gum, glukan, dan lignin yang membentuk chitosan mengikat asam lemak dan kolesterol sehingga tidak dapat membentuk misel yang dibutuhkan untuk hasil akhir pencernaan lemak. Apabila misel tidak terbentuk maka mengakibatkan penurunan jumlah lemak dalam tubuh. ${ }^{26}$

Hasil penelitian ini menunjukkan tidak ada perbedaan aktivitas fisik antara kelompok kasus dan kontrol $(\mathrm{p}=0,112)$. Sebanyak 93,33\% tingkat Physical Activity Level (PAL) pada kelompok kasus dan kontrol tergolong sangat ringan. Anak usia 3 - 5 tahun berada pada masa anak menjadi sangat aktif dalam bermain namun kemajuan teknologi membuat anak cenderung pasif dan melakukan sedentary lifestyle. Nilai PAL yang rendah pada kedua kelompok dapat disebabkan karena jarangnya anak melakukan olahraga dan sebagian besar anak menghabiskan waktu di rumah dengan bermain menggunakan gadget. Sebagian besar kegiatan yang dilakukan pada akhir minggu adalah pergi kepusat perbelanjaan dan makan bersama, atau bersantai di rumah. Nilai PAL yang tinggi didapatkan pada anak yang melakukan les olahraga pada hari sekolah dan akhir minggu. Les olahraga yang dilakukan pada anak yang memiliki nilai PAL tinggi adalah les renang dan les futsal. Aktivitas fisik adalah setiap gerakan fisik sebagai hasil dari adanya kontraksi otot skeletal dan diukur sebagai pengeluaran energi. Jika energi yang berasal dari asupan makan tidak digunakan untuk melakukan aktivitas fisik maka energi akan disimpan di dalam tubuh sebagai jaringan lemak. Hal ini dapat menyebabkan terjadinya obesitas. ${ }^{27}$ Manfaat aktivitas fisik antara lain dapat bermanfaat bagi perkembangan koordinasi otot dan gerakan tubuh, membantu anak mengatasi rasa resah dan stress dan menjaga berat badan ideal. ${ }^{11}$

Adanya teknologi yang semakin modern membuat anak semakin pasif dan memiliki gaya hidup yang santai (sedentary lifestyle). ${ }^{11}$ Penelitian menunjukkan bahwa sedentary lifestyle berhubungan dengan meningkatnya risiko terjadinya overweight dan obesitas. ${ }^{28}$ Obesitas cenderung menurunkan aktivitas, karena untuk mengurangi pergesekan antar kedua tungkai bagian atas dan antar lengan dada. Hal ini menyebabkan paru - paru dan jantung harus bekerja lebih berat untuk mengakomodasi kelebihan berat badan, dan peningkatan massa tubuh memerlukan tambahan energi untuk melakukan kegiatan yang sama. ${ }^{24}$

Aktivitas pada anak harus diperhatikan untuk mencegah obesitas. Hal ini sangat membutuhkan dukungan dari orang tua anak. Departemen Kesehatan Australia menyarankan untuk balita dan anak usia prasekolah untuk aktif bergerak sedikitnya 3 jam setiap hari yang dibagi dalam berbagai aktivitas sepanjang hari. Lembaga kesehatan di Amerika Serikat pada tahun 2011 merekomendasikan pentingnya aktivitas fisik selama satu jam setiap hari. ${ }^{29,30}$ Aktivitas yang dapat dilakukan pada anak dapat berupa kejar kejaran, lempar bola, bersepeda, berenang, bola kaki, jalan atau lari pagi. ${ }^{9}$

\section{SIMPULAN}

Terdapat perbedaan asupan lemak dan asupan energi antara kedua kelompok. Tidak ada perbedaan asupan serat dan aktivitas fisik antara kedua kelompok.

\section{SARAN}

Bagi sekolah, dapat melakukan penimbangan berat badan dan pengukuran tinggi badan yang hasilnya diberitahukan kepada orangtua siswa - siswi sehingga dapat mencegah 
terjadinya obesitas. Bagi orangtua murid, disarankan agar memberikan asupan energi dan lemak sesuai dengan kebutuhan anak dan mengganti camilan tinggi lemak dengan camilan dengan bahan dasar buah atau sayur seperti salad, puding buah, yoghurt.

\section{DAFTAR PUSTAKA}

1. De Onis M., Blössner M., Borghi E. Global Prevalence and Trends of Overweight and Obesity among Preschool Children. American Journal of Clinical Nutrition. 2010;92:125764.

2. Badan Penelitian dan Pengembangan Kesehatan Depkes RI. Riset Kesehatan Dasar 2010: Laporan Nasional. Jakarta: Balitbangkes Depkes RI, 2010.

3. Profil Kesehatan Kota Semarang tahun 2011.

4. Daniels SR, Arnett DK, Eckel RH, et al. Overweight in children and adolescents: pathophysiology, consequences, prevention, and treatment. Circulation 2005; 111; 19992002.

5. Cachera, M F Rolland. Deheeger M, Maillot $\mathrm{M}$ and Bellisle F. Early adiposity rebound: causes and consequences for obesity in children and adults. International Journal of Obesity (2006) 30, S11-S17.

6. Ohlsson C, Lorentzon M, Norjavaara E, Kindblom JM. Age at Adiposity Rebound Is Associated with Fat Mass in Young Adult Males. -The GOOD Study. PLoS ONE 7(11): e49404. doi:10.1371/journal.pone.0049404. 2012.

7. Hidayati, Siti Nurul. Irawan, Rudi. Hidayat, Boerhan. Obesitas pada Anak. Bagian/SMF Ilmu Kesehatan Anak. FK Unair/RS.dr.Soetomo. Surabaya. 2009.

8. Johnson, Laura. Mander, A.P. Jones, LR. Energy-Dense, Low-Fiber, High-Fat Dietary Patterns Is Associated With Increased Fatness in Childhood. Am J Clin Nutr. 2008:87;84654.

9. Kurniasih, Dedeh. Hilmansyah, Hilman. Astuti, Marfuah Panji. Imam, Saeful.Sehat dan Bugar Berkat Gizi Seimbang. 2010. Jakarta : PT.Gramedia

10. Brauchla M., Juan W., Story J., Kranz S. Sources of Dietary Fiber and the Association of Fiber Intake with Childhood Obesity Risk (in 2-18 Year Olds) and Diabetes Risk of Adolescents 12-18 Year Olds: NHANES 2003-2006. Journal of Nutrition and Metabolism 2012; 1-7.

11. Williams, Lipincott and Wilkins. 2005. Developmental and behavioural pediatrics, handbook for primary care. Second edition.
12. Mushtaq, M. Umair. Gull, Sibgha. Shahid, Ubeera. Shad, Mushtaq Ahmad. Akram, Javed. Dietary behaviors, physical activity and sedentary lifestyle associated with overweight and obesity, and their socio-demographic correlates, among Pakistani primary school children. International Journal of Behavioral Nutrition and Physical Activity 2011, 8:130

13. Mexitalia, M. JC, Susanto. Faizah, zinatul. Hardian.hubungan pola makan dan aktivitas fisik pada anak dengan obesitas usia $6-7$ tahun di Semarang. Media Medika Indonesia. 2005.

14. Zabinski et al. Overweight Children's Barriers to and Support for Physical Activity. Obes Res 2003; $11: 238-46$

15. Data Penimbangan Berat Badan dan Tinggi Badan siswa KB - TK Islam Al - Azhar 14 Semarang.

16. KEMENKES. Keputusan Menteri Kesehatan Indonesia Nomor: 1995/MENKES/SK/XII/2012 tentang Standar Antropometri Penilaian Status Gizi Anak. KEMENKES RI Direktorat Jenderal Bina Gizi dan Kesehatan Ibu dan Anak, Direktorat Bina Gizi 2011.p.4.

17. Dietary Reference Intakes For Energy, Carbohydrate, Fiber, Fat, Fatty Acids, Cholesterol, Protein, and Amino Acids, Institute of Medicine of the National Academies, 2002 and 2005

18. American Dietitian Association Institute of Medicine (IOM). Dietary Reference Intakes: The Essential Guide to Nutrient Requirements. In: Otten JJ., Hellwig JP, Meyers LD., editors. Washington, DC: THE NATIONAL ACADEMIES PRESS; 2006.p.84, 118.

19. FAO/WHO/UNU [Food and Agriculture Organization/ World Health Organization/ United Nations University]. Human Energi Requirement. Report of joint FAO/WHO/UNU Expert Consultation. Rome 17-24 Oktober 2001.

20. Sjostrom M, Ekelund U, Yngue A. Assessment of Physical Activity. Di dalam : Gibney MJ, Margetts BM, Kearney JM, Arab L, editor. Public Health Nutrition Oxford : Blackwell Publishing. 2008.

21. Carnell, Susan. Wardle, Jane. Appetite and adiposity in children: evidence for a behavioral susceptibility theory of obesity. Am J Clin Nutr. Am J Clin Nutr 2008;88:22 -9

22. Aycan, Zehra. Obesity in Childhood : Definition and Epidemiology. J Clin Res Ped Endo 2009;(Suppl 1):44-53

23. Vahouny, GV. Dietary Fiber; Chemistry, Physiology and Health Effects. New York : Plenum Press. 1999. 
24. Sjarif, Rusli Damayanti. Lestari, Dewi Endang, Mexitalia, Maria. Nasar, Sri Sudaryati. Buku Ajar Nutrisi Pediatrik dan Penyakit Metabolik. Jakarta : Badan Penerbit IDAI. 2011

25. Bowman SA, Gortmaker SL, Ebbeling CB, Pereira MA, Ludwig DS (2004) Effects of Fastfood consumption on energy intake and diet quality among children in national household survey. Pediatrics 113:112-118

26. Gropper SS, Smith JL, Groff JL. Advanced Nutrition and Human Metabolism $5^{\text {th }}$ ed. USA: Wadsworth Cengange Learning; 2009.p.115.

27. WHO, 2010; Physical Activity. In Guide to Community Preventive Services Web site, 2008

28. Saelens BE, Seeley RJ, van Schaick K, Donnelly LF, O'Brien KJ. Visceral abdominal fat is correlated with whole-body fat and physical activity among 8-y-old children at risk of obesity. Am J Clin Nutr 2007;85:46 -53.

29. Australian Government Department of Health and Ageing. (2004). National children and youth physical activity recommendations.

30. Institute of Medicine (IOM). Early Childhood Obesity Prevention: Policies Goals, Recommendations, and Potential Actions. 2011.

31. Ayu, Ratu. 2011. Faktor Risiko Obesitas Pada Anak 5-15 Tahun di Indonesia, Makara Kesehatan. Vol.5(1):37-43 